\title{
ORYX
}

The Journal of the Fauna and Flora Preservation Society

Editor Dr Jacqui Morris, Fauna and Flora Preservation Society, 79-83 North Street, Brighton, East Sussex, BN1 1ZA, UK

Editorial Board Dr Pat Morris (Chairman)

$\begin{array}{rcl}\text { Dr Kathleen Blanchard } & \text { Nicholas Hammond } & \text { Dr John Sparks } \\ \text { Dr Lee Durrell } & \text { Dr Chris Humphries } & \text { R.I. Vane-Wright } \\ \text { Maisie Fitter } & \text { Anthony Huxley } & \text { Dr Maureen Whalen } \\ \text { Dr Terry E. Graham } & \text { Brian Jackman } & \text { Edward Wright } \\ & \text { Dr Alison Jolly } & \end{array}$

Oryx is recognised as the leading international journal in the field of wildlife conservation. Each issue contains illustrated feature articles, news and views on topical conservation issues, a world-wide news digest, book reviews, correspondence and details of projects funded by the Society. It is aimed both at professional conservationists and those who wish to be well-informed about the dangers that threaten wildlife and what is being done to avert them.

Subscription Information

Oryx is published quarterly. Non-mem- ber subscription rates for 1990 are $£ 38.00$ (UK), $£ 44.00$ (overseas) and US\$73.50 (USA \& Canada) post free. Please complete the order form below.

\section{Membership Information}

Members receive Oryx free. Annual Membership: Standard $£ 20$, Family $£ 25$, Concessionary (students, retired, unwaged) $€ 12$, Associate $£ 10$, Benefactor $£ 35$, Life $£ 1,000$. Those wishing to join the Fauna and Flora Preservation Society, and receive Oryx as part of their subscription, should contact the FFPS at the address above.

\section{Order Form}

Please tick the appropriate box and return to:

Blackwell Scientific Publications Ltd, P.O. Box 88, Oxford, England.

I would like to subscribe, as a non-member of the FFPS, to Oryx

$\square$ I wish to pay by cheque and enclose the sum of $£$ US\$

$\square$ I wish to pay by Access/American Express/Barclaycard/Diners Card/

VISA/Mastercard (delete as neccessary)

Please debit my credit card no.

Expiry date with the sum of $£$ US\$

Signature Date

Please send me a specimen copy of Oryx

Name

Address 


\section{Seventy-six years of subscribers can't be wrong!}

\section{Join them and subscribe to}
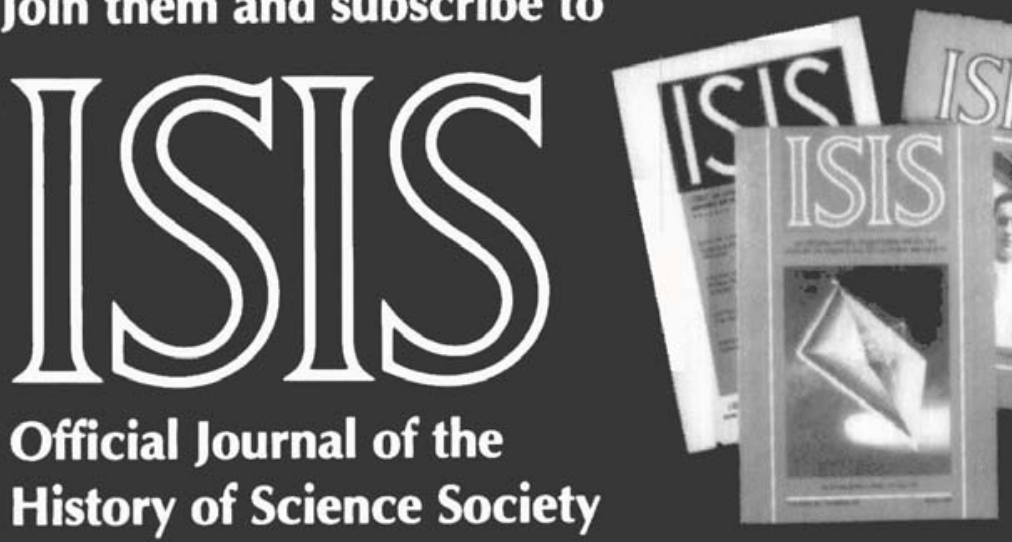

\section{Official Journal of the}

\section{History of Science Society}

The leading journal in the field, Isis goes to 4,500 subscribers in nearly fifty countries. Its articles, critiques, documents, and news of the profession keep professionals, educators, scholars, and graduate students well informed. Lively essay reviews and up to 300 book reviews a year cover every specialty in the history of science, technology, and medicine.

In 1990 Isis is publishing

ARTICLES by Larry Owens on MIT, the federal "angel," and R\&D; by Mario Biagioli on Galileo the emblem maker; by Neal Gillespie on William Paley and the Industrial Revolution; and by Sally Gregory Kohlstedt on science education in early nineteenthcentury America

A SPECIAL REVIEW SECTION on journals in the history, philosophy, and social studies of science, technology, and medicine ESSAY REVIEWS by Owen Hannaway of Peter Dear on Mersenne and Lynn Sumida Joy on Gassendi, by Susan Douglas of The Social Construction of Technological Systems, and by Nathan Sivin on Paul U. Unschuld's Medicine in China

\section{AND MUCH MORE!}

Subscription to Isis also brings - membership in the History of Science Society $\bullet$ the annual Current Bibliography, listing over 3,000 recent publications in the field • the quarterly Newsletter, providing current news on jobs, meetings, fellowships, and other opportunities • the 1990 Guide to the History of Science, listing members and describing programs, societies, journals, and newsletters in the field-coming this summer! • reduced rates for Osiris, the Society's research annual.

Write to: History of Science Society, Dept. 1-14

215 South 34th Street

Philadelphia, PA 19104-6310 


\section{SCIENCE PROGRESS}

a review journal of current scientific advance

EDITORS

\section{Professor J.M. Ziman FRS}

Science Policy Support Group, London

Professor Patricia Clark FRS

Department of Chemical and Biochemical Engineering, University College London

Science Progress was first published in 1894, and its primary object has always remained the same - to publish articles written by experts to explain the latest developments in their own speciality to their colleagues working in other fields. Some of the most spectacular advances in science arise from the fusion of two or more disciplines, such as that of physics and chemistry with genetics to produce molecular biology. In this situation the journal's current practice of presenting non-specialist reviews is particularly valuable. It seeks as far as possible to emphasize current progress on the borderlines of the scientific disciplines in the hope that it may further the unification of science and stimulate scientists to think about problems outside their own immediate fields of interest.

\section{Subscription Information}

Science Progress is published quarterly. Subscription rates for 1990 are $£ 54.50$ (UK), £63.00 (overseas) and US\$105.00 (USA \& Canada) post free.

\section{Order Form}

Please tick the appropriate box and return to:

Blackwell Scientific Publications Ltd, P.O. Box 88, Oxford, England.

$\square$ I would like to subscribe to Science Progress

$\square$ I wish to pay by cheque and enclose the sum of $£$ US\$

$\square$ I wish to pay by Access/American Express/Barclaycard/Diners Card/

VISA/Mastercard (delete as neccessary)

Please debit my credit card no.

Expiry date with the sum of $£$ US\$

Signature Date

$\square$ Please send me a specimen copy of Science Progress

Name

Address 


\section{STUDIES IN HISTORY \& PHILOSOPHY OF SCIENCE}

Editor: NICHOLAS JARDINE, Department of History \& Philosophy of Science, University of Cambridge, Free School Lane, Cambridge CB2 $3 R H, U K$

Associate Editor: ANDREW CUNNINGHAM, Wellcome Lecturer in the History of Medicine, Department of History and Philosophy of Science, University of Cambridge, Cambridge, UK Senior Consulting Editor: GERD BUCHDAHL, Department of History \& Philosophy of Science, University of Cambridge, Free School Lane, Cambridge CB2 3RH, UK

Book Review Editor: JENNY WARD.

Studies in History \& Philosophy of Science is essential reading for students and teachers concerned with the historical, social and intellectual contexts of the sciences and with their methodology and epistemology.

The journal particularly encourages studies which integrate philosophical, historical and sociological considerations. Its orientation is international, with contributions from a wide range of cultural perspectives.

The papers published are of the highest scholarly quality. Since the journal's inception it has proved an invaluable source both for reflective scientists and for workers in the history, philosophy and sociology of science.

Relevant papers are welcome for editorial consideration.

A Selection of Papers

EDUARD GLAS (The Netherlands), Testing the philosophy of mathematics in the history of mathematics. Part II: the similarity between mathematical and scientific growth of knowledge.

PHILIP MIROWSKI (USA), How not to do things with metaphors: Paul Samuelson and the science of neoclassical economics.

DAVID B RESNIK (USA), Adaptationist explanations.

DOUGLAS M JESSEPH (USA), Philosophical theory and mathematical practice in the seventeenth century.

ANDREW D WLSON (USA), Hertz, Boltzmann and Wittgenstein reconsidered.

Indexed/Abstracted In: Curr Cont Arts \& Hum Cit Ind, Curr Cont ASCA, ASSIA, Biosis Data, Curr Cont/Soc \& Beh Sci, Math R, Sociol Abstr, Curr Cont Soc Sci Cit Indx

(00401)

1990: Volume 21 (4 issues)

Annual subscription (1990) DM 350.00

Two-year rate (1990/91) DM 665.00

ISSN: 0039-3681

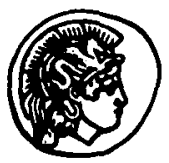

\section{PERGAMON PRESS}

Member of Maxwell Macmillan Pergamon Publishing Corporation

Pergamon Press plc, Headington Hill Hall, Oxford OX3 OBW, UK

Pergamon Press, Inc., Maxwell House, Fairview Park, Elmsford NY 10523, USA

Advertising rate card available on request. Back issues and current subscriptions are also available in microform. The DM prices shown include postage and insurance. For subscription rates in the Americas, Japan, UK and Eire please contact your nearest Pergamon office. Prices and proposed publication dates are subject to change without prior notice. 


\section{THE BRITISH SOCIETY FOR THE HISTORY OF SCIENCE}

Membership of the Society, which normally includes a subscription to The British Journal for the History of Science, is open to all persons approved by the Council of the Society and elected at an ordinary meeting. The annual subscription for the membership year 1990 is $£ 18.50(\$ 40.00)$ or $£ 9.25(\$ 25.00)$ for associate membership, which includes students at centres of higher education. There is an Introductory Offer for ordinary members who pay $£ 14.00$ (\$30.00) for the first year. Applications for membership should be made on a form which is available from the Society's Executive Secretary at the address below.

Meetings: The Society mounts an ambitious programme of meetings. The pattern is flexible, the only fixture being the three day summer meeting, held at a different British University or Polytechnic each year. About four other meetings, lasting for between one and three days, are held during the year, sometimes devoted to a clearly-defined theme or an important anniversary, and often arranged in conjunction with other scholarly societies.

The British Journal for the History of Science is the official organ of the Society. All correspondence on the contents of the Jourmal should be addressed to the Editor, Dr J. H. Brooke, Department of History, University of Lancaster, Lancaster LA1 4YG, England.

Books for review should be sent to the Reviews Editor, Dr John Henry, Science Studies Unit, University of Edinburgh, 34 Buccleuch Place, Edinburgh EH8 $9 \mathrm{JT}$.

Advertising: Contact the Advertising Department, Blackwell Scientific Publications, Osney Mead, Oxford, OX2 0EL. Fax no. (0865) 721205.

Other publications: BSHS Monograph Series is designed to allow the publication of monographic studies in the history of science quickly and cheaply. All correspondence on the subject of monographs, and any new suggestions for titles, should be sent to the Series Editor, Dr J. G. Smith, Department of History, University of Leicester, Leicester, Leics LEI 7RH, England. Monographs are available to members at a special price, post-free from the Society's Executive Secretary. Non-members may obtain them through bookshops, or post-free from the Executive Secretary. Titles are as follows:

2. The Letlers of Georges Cuvier: A Summary Calendar. Ed. by Dorinda Outram. 1980. $£ 4.50 / \$ 10.00$ ( $£ 3.50$ / $\$ 8.00$ to members).

3. Rationality and Ritual: The Windscale Inquiry and Nuclear Decisions in Britain. By Brian Wynne. 1982. $27.00 /$ $\$ 15.00$ ( $\$ 5.00 / \$ 11.00$ to members).

4. The Royal Society and Its Fellows 1660-1700: The Morphology of an Early Scientific Institution. By Michael Hunter. 1982, reprinted 1985. $£ 9.00 / \$ 19.00$ ( $\$ 6.50 / \$ 14.00$ to members).

5. Francis Bacon's Natural Philosophy: A New Source. A Transcription of Manuscript Hardwick $72 A$ with Translation and Commentary. By Graham Rees, assisted by Christopher Upton. 1984. $£ 7.90 / \$ 17.00$ ( $£ 5.60 / \$ 12.00$ to members).

6. Archives of the British Chemical Industry, 1750-1914: A Handlist. By Peter J. T. Morris and Colin A. Russell. Contributing editor John Graham Smith. 1988. $£ 14.50 / \$ 31.00$ ( $\$ 9.00 / \$ 19.00$ to members).

Lists of theses: Each year, the Society publishes a full list of current theses in history of science in British universities. This is available free to members, and at $£ 3.00(\$ 6.00)$ to non-members on request to the Executive Secretary. Standing orders are accepted from members or non-members who wish to receive the list regularly.

The Society's Newsletter, an informal publication edited by Dr Frank A. J. L. James, RICHST, The Royal Institution, 21 Albemarle Street, London WIX 4BS, appears in January, May and September each year. It is free to members, $£ 6.00(\$ 12.00)$ for institutions and non-members.

All the administrative business of the Society is handled by The Executive Secretary, Wing Commander G. Bennett, 31 High Street, Stanford in the Vale, Faringdon, Oxfordshire SN7 8LH. 


\section{The British Journal for the History of Science}

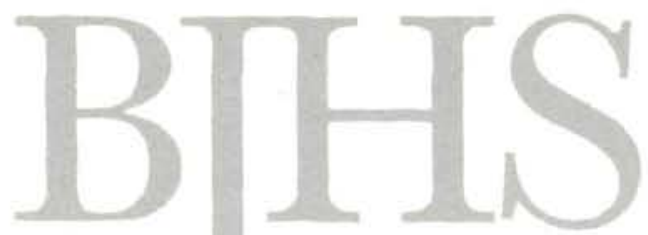

Volume 23 Part 2 No. 77

\section{June I990}

I29 Editorial

I3I D.W.Jordan: The Magnetic Circuit Model, 1850-1890: The Resisted Flow Image in Magnetostatics

I75 Colin A. Russell and Shirley P. Russell: The archives of Sir Edward Frankland: Resources, Problems and Methods

I87 Alberto Elena and Javier Ordonez: History of Science in Spain: A preliminary survey

\section{Essay Reviews}

I97 Antonio Perez-Ramos: Francis Bacon and astronomical inquiry

207 John V. Pickstone: A profession of discovery: Physiology in nineteenth-century history

217 Book Reviews

253 Books Received

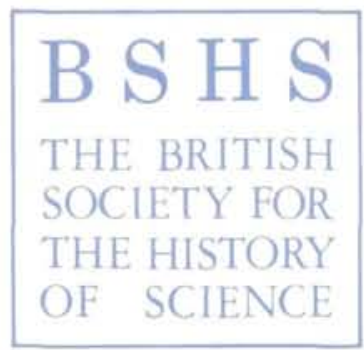

Published for The British Society for the History of Science

by Blackwell Scientific Publications

Oxford · London · Edinburgh · Boston - Melbourne · Paris ·

Berlin · Vienna

(C) The British Society for the History of Science 1990

Printed in Great Britain at the Alden Press, Oxford 